\title{
WHAT GOVERNMENT EFFORTS ARE BEING MADE TO ASSIST SMALL BUSINESS
}

\author{
WENDELI BARNES*
}

\section{The President's Council of Economic Advisers has stated, ${ }^{1}$}

The Federal Government makes its greatest contribution to the welfare of small business by following policies that help maintain stable prosperity. A vigorous growing economy offers ample opportunities not only for established firms to grow in size and strength, but also for new businesses to be started. Small businesses are aided in this respect by Federal policies that maintain confidence on the part of investors, businessmen and consumers, that eoncourage risk taking and that preserve and strengthen competition.

The best testimonial to the vitality of small business is the number of small businesses in our economy. It is inaccurate to say that small business is in a situation of distress today. The number of small businesses is at the highest level in all history. There were 4,323,000 businesses as of January $x, 1958$, an increase of 33,700 over the preceding year. Of this number, nearly $4,200,000$ may be considered as small. In the preceding year, there was an increase of 43,800 , and in the year ending January $I$, 1956 , there was an increase of 56,200 .

After World War II a large number of persons, prompted in part by the opportunities offered in the so-called "G. I. Bill," launched small business ventures. Since many of these people lacked experience, their prospects for survival were doubtful. As was to be expected, there have been casualties in sizable quantity. Despite this, the total number of small businesses has continued to increase. In fact, the number of such businesses in existence today is one-third greater than it was before the war.

It should be noted that bankruptcy figures may be misleading, and have, in fact, been subject to wide misinterpretation. Of the total number of bankruptcies in fiscal $1957-73,76 \mathrm{r}$-only 9,535 were business bankruptcies; all the rest were personal bankruptcies. The total bankruptcy figures, including preponderantly personal bankruptcies, therefore, should not be used as a small business indicator.

Small businesses benefit from a large number of federal policies and programs adopted to assist business concerns generally, both large and small, and from a growing number of programs designed specifically to help small concerns. I shall describe the most important of these policies and programs.

\section{I}

Development of Smali Business Programs

Federal government assistance with the special problems of small business began in I94I. In that year, a Small Business Unit was established in the Bureau of Foreign

- A.B. I932, Brown University; LL.B. I935, University of Michigan. Administrator, Small Business Administration, since r953; member of the Oklahoma bar.

${ }^{1}$ Federal Policies and Programs That Benefit Small Business I (I957). 
and Domestic Commerce of the United States Department of Commerce, and it was directed to: (I) study the small business segment of the nation's industries; (2) determine the problems encountered by smaller firms because of their size; and (3) plan a program to assist the firms with their problems.

This small business program of the Commerce Department had been under way only a short time when World War II began. During the ensuing years, several of the projects initiated by the Commerce Department unit were adopted by the War Production Board and the Smaller War Plants Corporation. These projects related primarily to smaller manufacturers. 'The wholesale, retail, and service trades continued to be served by the Commerce Department. Throughout the war years, the Commerce Department carried on a limited small business program devoted chiefly to advice on management problems and the distribution of marketing and economic information.

The major effort to bring small manufacturers into war-supporting industries during World War II began with the establishment of the Smaller War Plants Corporation (SWPC) as a part of the War Production Board on June II, I942. Earlier attempts to increase small business participation in the war effort, first through the work of the Division of Contract Distribution of the Office of Production Management, and later through the work of two units of the War Production Board-the Contract Distribution Branch, Production Division, and the Bureau of Finance, Division of Industry Operations-had met with little success. By April I943, the SWPC had been separated administratively from the War Production Board, although the Chairman of the Board of the SWPC continued to serve the War Production Board in an advisory capacity as its Vice-Chairman for Smaller War Plants.

The SWPC was authorized by Congress to carry on two broad types of activities: to help small manufacturers obtain prime and subcontracts for war production, and to make loans to small firms. Specifically, the SWPC was authorized to: (I) direct the attention of government procurement officers to the potential productive capacity of small plants, and to certify the competency, as to capacity and credit, of small businesses to perform procurement contracts; (2) assume government procurement contracts, which it could then subcontract to small firms; (3) encourage subcontracting by large prime contractors; (4) make loans to small plants for defense and essential civilian purposes; (5) make a complete inventory of productive facilities which could be used in the war effort; (6) approve war production pools; (7) lease or sell equipment and land to small business; (8) assist small firms in obtaining essential materials; and (9) assist manufacturers in solving their production problems.

Additional duties subsequently were given to the SWPC under the Contract Settlement Act, the Surplus Property Act, the Servicemen's Readjustment Act, and the War Mobilization and Reconversion Act. ${ }^{2}$ The most important of these were to:

\footnotetext{
${ }^{2} 58$ Stat. 649 (I944), 4 I U.S.C. \$ IOI (I952); 58 STAT. $765 ; 58$ STAT. 284 (I944), 38 U.S.C. \$\$ 693 et seq. (1952); 58 StaT. 785 (1944).
} 
(I) make loans to small plants pending settlement of their government contracts, and to give other contract settlement assistance; (2) assist small businesses and veterans in obtaining surplus property, and to make loans to small businesses for this purpose; and (3) see that small businesses obtained a fair share of scarce materials as they were released to civilian production.

As of January 1946, the SWPC was abolished by Executive Order. ${ }^{3}$ Its loan functions were transferred to the Reconstruction Finance Corporation, and its other functions to the Department of Commerce (except veterans' functions, which went to the War Assets Corporation). However, during the approximately three and onehalf years of its existence, the SWPC had helped small plants to obtain about 54,000 prime contracts valued at over $\$ 6,000,000,000$ and had made loans and leases to small plants amounting to approximately a half billion dollars.

The SWPC functions that were transferred to the Commerce Department were combined with the small business functions that the Department had continued during the war and were placed in a new unit, the Office of Small Business. The programs were modified, of course, to meet changed conditions. The main functions of the Office of Small Business were to: (I) assist small businesses with their management problems, such as record-keeping and advertising; (2) provide prospective small businessmen with basic information on the types of businesses they planned to enter; (3) assist state planning commissions and other groups in surveying the industrial and other resources of specific areas to determine what types of new small businesses could make use of the resources; (4) seek the elimination of monopolistic and unfair trade practices that were harmful to small business; (5) provide small manufacturers with information on government procurement and encourage the awarding of an increased proportion of contracts to small business; (6) study the tax problems of small business and the probable effect upon small business of proposed tax legislation, and make recommendations as to both; (7) study the overall financial problems of small business and assist individual small businesses with their financial problems; and (8) help small manufacturers solve their production problems.

Following the passage of the Defense Production Act of $1950,{ }^{4}$ and the establishment of the National Production Authority, the Office of Small Business became a primary unit of the NPA. The office then began to devote most of its efforts to its government procurement program, research on production and economic problems of small business resulting from the defense program, and assistance to small business in obtaining scarce materials.

On July 3I, I95I, by unanimous action, Congress created the Small Defense Plants Administration (SDPA) by adding section $7 \mathrm{I}_{4}$ to the Defense Production Act. ${ }^{5}$ After establishment of the Small Defense Plants Administration, and assignment to it of

${ }^{3}$ Exec. Order No. 9665 , Dec. 27, 1945; xo Fed. Reg. 15365 (1945).

- 64 StAT. 798, 50 U.S.C. App. \$ 2061-66 (1952).

"65 STAT. 13I (195X), 50 U.S.C. App. $\$ 2 \times 632$ (1952). 
the major responsibility for increasing small business participation in the defense effort, many of the functions of the Office of Small Business were transferred thereto by the President. The principal functions of the Small Defense Plants Administration, as prescribed by Congress, were to see to it that small business: ( $I$ ) obtained a fair share of defense contracts; (2) received a fair share of critical materials; and (3) obtained the financial and technical assistance needed to participate effectively in defense and essential civilian activities.

The SDPA provided a minimum of $\$ 723,744,379$ worth of assistance to small business concerns, chiefly manufacturers, in its twenty-one months of operation. This is the total dollar value of government procurement (prime contracts and subcontracts) and loans obtained for small plants through the agency's efforts, and does not reflect the value of additional assistance for which methods of reporting and computing were not available.

In I953, the Small Business Administration (SBA) was established as the first independent agency of the Government charged with the duty of fostering the interests of small business. ${ }^{6}$ For the first five years of its existence, the SBA resembled the SWPC in the sense that it was only a temporary agency designed primarily to assist small business in meeting problems created by the defense effort. The most important difference between the two agencies was that the lending powers of the SBA were not, like those of the predecessor agency, confined to defense or essential civilian purposes. Even at this stage of its development, the SBA could and did make loans to small businesses for peacetime purposes. Indeed, most of its loans have been of that nature.

In 1958, the Small Business Act ${ }^{7}$ was enacted to convert the SBA into a permanent establishment expressly authorized to assist small businesses in meeting all problems, including those which have no relation to national defense. This change in the character of the Administration resulted from the recognition, by the President and the Congress, that it was advisable to stabilize and strengthen the small business program and to extend its operations into the peacetime economy.

The authority of the SBA was broadened correspondingly. For example, the Act calls upon the SBA to explore all matters materially affecting the competitive strength of small business and to study the effect on small business of all federal laws, programs, and regulations. Similarly, programs to assist small business in obtaining government contracts are placed on a peacetime basis. The SBA is authorized to furnish such assistance for all types of federal procurement without the former requirement that the assistance be related to war or defense programs.

Even before the authority of the SBA was thus formally expanded to cover the peace-time needs of small business, the President had established a program integrating the resources of the federal government for the purpose of studying and

\footnotetext{
6 67 STAT. 232 (I953), 15 U.S.C.A. $\$ 63$ I (Supp. I959).

${ }^{7} 72$ Stat. 384 (I958), 55 U.S.C.A. \$\$ 631-47 (Supp. 1959).
} 
resolving all problems affecting this vital segment of the economy. On May $3^{\mathrm{r}, ~} 195^{6}$, he established the Cabinet Committee on Small Business, composed of the Secretary of Defense, the Secretary of Commerce, the Secretary of Labor, the Director of the Office of Defense Mobilization, the Administrator of the Housing and Home Finance Agency, the Administrator of the Small Business Administration, and the Chairman of the Council of Economic Advisers. The latter is Chairman of the Committee. In his explanation of this action, the President declared: ${ }^{8}$

The important contributions made by small business concerns to the progressive spirit and vitality of the American economy have repeatedly been stressed in my economic reports. ... The Federal Government has a number of programs now in operation that are significantly helpful to small business. ...

These and other.programs and policies of the Federal Government facilitate the establishment of new concerns and foster the growth of small businesses. Yet the conditions of our modern economy are such that many small concerns confront substantial hindrances to their growth. It is my wish that the Federal Government keep fully abreast of developments that affect small businesses. ... .

To this end I am establishing a Cabinet Committee on Small Business. . . The Committee is to have the continuing assignment of making specific recommendations to me for administrative actions and, where necessary for additional legislation, to strengthen the economic position of small businesses and to foster their sound development.

In its first Progress Report, dated August 7, 1956, the Committee made fourteen recommendations for the betterment of the interests of small business, nine of which have since been carried out. The first four recommendations, calling for changes in the tax laws, are reserved for separate discussion below. The remainder are considered here.

Number five, recommending a comprehensive review of procurement policies, including the legislation pertaining thereto, has been implemented by the Omnibus Procurement Act, ${ }^{9}$ which makes it easier for small business concerns to do business with the Government by permitting extension to most civilian agencies of a modernized procurement code. In addition, it makes important improvements in connection with the authority to make advance and progress payments and simplifies payroll information required by the Anti-Kickback $\mathrm{Act}^{10}$ relating to government construction and building repair contracts. This Act also facilitates further implementation of a related recommendation-number six-that administrative action be taken to remove certain obstacles which hinder or delay advance and progress payments to small contractors.

Number seven recommending that the Renegotiation Board encourage government contractors to subcontract their work by making it clear that such subcontracting is given favorable consideration in determining allowable profits, has been implemented by an appropriate amendment to the regulations of the Board.11 Number

${ }^{8}$ Cabinet Committee on Smali. Business, Progress Report app. 13-I4 (1956).

${ }^{\circ} 72$ STAT. 966 (r958), 4 I U.S.C.A. $\$ 252$ and 40 U.S.C.A. $\$ 276 \mathrm{c}$ (Supp. I959).

${ }^{10} 48$ STAT. 948 (1934), I8 U.S.C. $\$ 874$ and 40 U.S.C. $\$ 276 \mathrm{c}$ (1952).

11 Renegotiation Board Regs. $\$$ 1460.14, 2 CCH Gov't CONT. REP. I 26I44 (I958). 
eight, calling for an extension of the life of the Small Business Administration has been carried out by legislation ${ }^{12}$ establishing the $\mathrm{SBA}$ as a permanent agency of the Government.

Number nine, recommending that the maximum amount of an issue of corporate securities which the Securities and Exchange Commission may exempt from registration be increased from $\$ 300,000$ to $\$ 500,000$, was embodied in a proposal ${ }^{13}$ which passed the Senate on June 26, 1957. However, the House Committee on Interstate and Foreign Commerce, to which it was referred, took no action thereon. Number ten, calling for a conference on technical research, development and distribution, for the benefit of small business, was carried out by a conference held in Washington on September $24-26, \mathbf{x} 95^{8}$.

Number eleven recommends closer federal scrutiny of mergers. A bill implementing this proposal was reported from the House Committee on the Judiciary on May 28, $1957^{14}$ However, it made ho further progress.

Number twelve, recommending procedural changes in the antitrust laws to facilitate their enforcement, was partially implemented by bills ${ }^{15}$ which make cease and desist orders of the Federal Trade Commission final when issued, unless appealed to the courts. The Senate bill passed the Senate on July 15, 1958, but the House took no action on either. Number twelve was further implemented by a bill10 providing that, when civil rather than criminal proceedings are being considered, the Attorney General be empowered to issue a civil investigative complaint compelling the production of relevant documents before the filing of a complaint, without having to invoke grand jury proceedings. No action had been taken on this bill when the Congress adjourned in 1958 .

Number thirteen, recommending that wage reporting by employers for purposes of social security records and income tax withholding be simplified, was embodied in a bill which was still pending in the Ways and Means Committee when the Congress adjourned. ${ }^{17}$

Number fourteen recommends that the Office of Statistical Standards of the Bureau of the Budget undertake a comprehensive review of the reports and statistics required of small businesses. The Federal Reports Act of $1942^{18}$ requires that any government agency which desires to collect information from private persons or businesses shall submit the plan or form to the Director of the Bureau of the Budget for approval. As part of its normal review, the Office of Statistical Standards now examines such plans from the standpoint of their effect as burdens on small business.

\footnotetext{
${ }^{12} 72$ StAT. $3^{84}$ (1958), I5 U.S.C.A. $\$ \$ 631-47$ (Supp. 1959).

${ }^{18}$ S. 2299, 85th Cong., rst Sess. (1957).

${ }^{14}$ H.R. 7698, 85th Cong., Ist Sess. (1957).

${ }^{15} S .721$ and H.R. 8682, 85th Cong., Ist Sess. (1957).

${ }^{16}$ S. 1023, 85th Cong., rst Sess. (1957).

${ }^{17}$ H.R. 8309 , 85th Cong., Ist Sess. (1957).

${ }^{18} 56$ STAT. I078, 5 U.S.C. $\$ \$$ I39-39f (1952).
} 
II

\section{Small Business Tax Benefirs}

Until recently, the Department of the Treasury and Congress have been reluctant to give special consideration to small business tax problems. The Technical Amendments Act of $195^{819}$ represents a change in this attitude. It contains six changes in the tax laws which are of direct benefit to small business concerns. Three of these stem from recommendations made by the Cabinet Committee on Small Business in its first report of August 7, 1956, and another carries out a recommendation made by the President in a letter addressed, on July 15, 1957, to the Chairman of the House Committee on Ways and Means. ${ }^{20}$

Section sixty-four of the Act permits small corporations to be treated as partnerships for income tax purposes. Where all of the shareholders of such a corporation elect to take advantage of this provision, each shareholder will include in his own income, for tax purposes, his proportionate share of the current taxable income of the corporation, both the portion which is distributed and that which is not. The right to this election is limited to domestic corporations which have no more than ten shareholders and no more than one class of stock. This section applies to taxable years beginning after December 31, I957.

In the case of undistributed corporate earnings, this election will be of value to shareholders who have marginal tax rates below the rate payable by the corporation. Where the earnings are distributed (and are in excess of what may properly be classified as salary payments), the benefit will extend to shareholders with somewhat higher rates, since, in this case, a "double" tax is removed. The section will also be of substantial benefit to small corporations realizing losses for a period of years where there is no way of offsetting such losses against taxable income at the corporate level and where the shareholders involved have other income which can be used as an offset.

In 1954, legislation was enacted permitting proprietorships and partnerships to elect to be taxed like corporations. ${ }^{21}$ The combined effect of that elective right and the elective right granted by section sixty-four is to reduce the importance of tax consequences as a consideration in determining which of the three forms a business enterprise should assume.

Section 202 of the Act provides ordinary loss, rather than capital loss, treatment on stock of small business corporations which is sold or exchanged at a loss or which becomes worthless. This right is available only in the case of an individual and only if he is the original holder of the stock. To limit the benefits of this provision to small business, the aggregate of the stock offerings of any corporation which are eligible for the ordinary loss treatment is limited to $\$ 500,000$. The total stock offering per corporation plus the equity capital of the corporation may not exceed

${ }^{10} 72$ STAT. 1606 (codified in scattered sections of 26 U.S.C.).

$30 I d . \$ \$ 64,204,206$, and 202 .

${ }^{21}$ INT. REv. CoDE of 1954 , $\$ 136 \mathrm{r}$. 
$\$ 1,000,000$. In addition, the maximum loss that can be taken by a taxpayer is $\$ 25,000$ a year (or $\$ 50,000$ in the case of a husband and wife filing a joint return).

The effect of section 202 is to bring shareholders in a small corporation closer, from the standpoint of risk, to the status of proprietors or partners. The result should be to make equity capital more readily available to small corporations.

Section 203 of the Act extends the former two-year net operating loss carry-back to a three-year carry-back with respect to losses carried back from the calendar year $195^{8}$ (or from the portion of a fiscal year falling in 1958) and the following years. Thus, a loss is first carried back to the third year before the year of the loss. If any loss then remains, it is carried to the second year before the loss, and any loss then remaining is carried to the first year prior to the loss. At that point, the carryforward provisions of the law, which remain unchanged, come into play. Any loss still remaining is carried successively to the five years after the year of the loss.

The addition of one year to the net operating loss carry-back will not increase the loss offsets that have been available to small businesses, incorporated and unincorporated, since those which could not entirely offset a loss in the two prior years could usually do so against income in the five succeeding years. The primary intent of section 203 is to benefit small firms whose losses during calendar year 1958 exceed their 1957 and 1956 income. By taking their losses back to 1955 , which was a good year for many, they may obtain badly needed money by way of tax refunds from the Government.

Section 204 of the Act permits a taxpayer to write off twenty per cent of the cost of depreciable, tangible personal property, having a useful life of six years or more, in the year of acquisition. This treatment, which is applicable to newly acquired used property as well as new assets, is available for taxable years ending after June 30, 1958, on property acquired after December 3I, 1957. The benefits of section 204 are concentrated largely in the small business area by limiting that part of the cost of property, with respect to which the write-off can be taken, to a value not in excess of $\$ 10,000$ (\$20,000 in the case of a husband and wife fling a joint return).

A write-off of one-fifth of the total cost of an asset in the year of its acquisition, in addition to regular depreciation on the balance, will make it possible for small business to use depreciation reserves not only for replacement, but also, to a significant degree, for expansion. In addition, it should encourage additional investment in small business, since it provides for a faster recovery of capital before the taxing of earnings.

Section 205 of the Act relates to the accumulated earnings credit. In addition to the regular corporate income tax, the Internal Revenue Code of $x 954$ imposes an accumulated earnings tax (formerly called the section ro2 tax) of $27-1 / 2$ to $38-1 / 2$ per cent on improperly accumulated corporate earnings. ${ }^{22}$ In computing the income base on which this tax is imposed, there is excluded an amount equal to the earnings and profits of the taxable year which are retained for the reasonable needs of the

${ }^{22}$ INT. Rev. CODE of 1954, § 53 T. 
business. Prior to the enactment of section 205, there was a minimum credit of $\$ 60,000$ of earnings which could be accumulated before any income was subject to the accumulated earnings tax. This section raises that minimum to $\$ 100,000$. It is effective with respect to taxable years beginning after December 3I, 1957 .

The accumulated earnings tax has presented an especially serious problem for small business, because the absence of specific plans for the future frequently makes it difficult for a small concern to establish the fact that the earnings are accumulated for reasonable needs of the business. In fact, it was this difficulty which initially led to the establishment of the $\$ 60,000$ minimum. By raising this amount to $\$ 100,000$, allowance is made for cost increases which have occurred since the original figure was established. It should be emphasized that the increase in the minimum credit is in no way intended an an indication that accumulated earnings in excess of $\$ 100,000$ are necessarily subject to the earnings tax.

Section 206 provides that, where the value of an interest in a "closely held business" represents a significant portion of the base on which the federal estate tax is computed, the federal death tax can then be paid in ten annual installments rather than in one lump-sum payment fifteen months after the death of the decedent. To be eligible for this treatment, the interest in a closely held business (or the aggregate interests in several businesses, if the interest in each is more than half) must represent thirty-five per cent of the gross estate or fifty per cent of the taxable estate of the decedent. A "closely held business" is defined in the section as including a proprietorship, a twenty per cent capital interest in a partnership, a twenty per cent stock interest in a corporation, and an interest in a partnership or corporation in which there are ten or fewer partners or shareholders.

This tax deferral is, of course, available only with respect to the portion of the estate tax attributable to the value represented by the interest in the closely-held business. Installment payments made under a deferral arrangement are subject to interest at the rate of four per cent. Section 206 applies to estates of decedents where the date of filing the federal estate tax return falls later than September 2, 1958, the date on which the Technical Amendments Act of $195^{8}$ was enacted.

Section 206 is designed primarily to keep a business enterprise intact where the death of one of the larger owners of the business results in the imposition of a relatively heavy estate tax. The hope is that, by spreading the period over which the estate tax may be paid, it will be possible to pay the estate tax out of the earnings of the business. This provision should play an important part in current efforts to prevent the absorption of small businesses by their larger competitors.

\section{III}

\section{Financial Assistance Programs}

The federal government has a number of programs for helping small business meet their credit and capital needs. Chief among these are the programs administered by the Small Business Administration, the first federal agency to be organized 
with exclusive responsibility for helping small businesses solve their financing problems. The SBA places special emphasis on facilitating the access of small concerns to private sources of funds; however, where necessary, it extends credit directly to businesses that are unable to obtain adequate financing on reasonable terms.

In line with its policy of facilitating the access of small concerns to private sources of credit, the SBA participates with banks and other private lending institutions in the extension of credit to such businesses. Its participation loan programs are designed to help maintain the borrowing firm's relationship with its local bank and to encourage private lenders to make loans to firms applying for SBA assistance. Participation arrangements are of two types: (I) The SBA and the co-operating bank each advances part of the funds when the loan is first made; these are known as immediate participation loans. (2) The SBA does not advance any funds at the outset, but agrees at the option of the co-operating bank, to purchase up to a specified part of the loan at a later date; these are known as deferred participation loans. Where participation with a private lender cannot be arranged, the SBA may extend the full amount of the loan under its direct loan program.

Through December 3 3 , 1958, the SBA had approved 8,977 participation loans, totaling approximately $\$ 443,000,000$. Of this amount, the SBA share was $\$ 342,000,000$; private lending institutions committed themselves to extend the remainder. About $\$ 317,000,000$ has been disbursed by the SBA and co-operating banks under these participation loans as of December 3I, 1958. The SBA has also approved 4,76r loans in which no participation with a private lending institution was involved. Under this direct loan program, $\$ 196,000,000$ of credit was approved through December 3I, I958, and approximately $\$ 135,000,000$ had been disbursed.

Participation loans and direct loans are made with maturities up to ten years, except that a loan made for the purpose of constructing facilities may have a maturity of ten years plus such additional period as it is estimated may be required to complete such construction. Prior to August $195^{8}$, the maximum interest rate was six per cent per annum; since that date the maximum rate on the SBA share has been reduced to $5-1 / 2$ per cent per annum.

The SBA also has a special loan program called the Limited Loan Participation Program, particularly designed to meet the credit needs of small retail, wholesale, and service firms. Under this program, approval of a loan can be authorized by the Regional Director of any one of the SBA's fifteen regional offices if ( $\mathrm{I}$ ) at least twentyfive per cent of the loan is extended by a private financing institution, (2) participation by the SBA is not over $\$ 15,000$, and (3) the loan terms call for full repayment in monthly installments over a period not exceeding five years. The maximum interest rate on the SBA share of these loans was also reduced from six per cent to 5-1/2 per cent in August $195^{8}$. Through December 3r, 1958, 3,662 loans totaling $\$ 53,600,000$ had been approved under this program. These figures are included in the data shown above for participation loans. 
Under the so-called "pool loan" program, the SBA makes loans to corporations formed and capitalized by a group of small business concerns for the purpose of obtaining for the use of such concerns raw materials, equipment, inventories, supplies, or the benefits of research and development, or for establishing facilities for such purpose. These loans are limited by the Small Business Act of $195^{8}$ to a maximum of $\$ 250,000$ multiplied by the number of small businesses that have established the pool corporation. To date, only three business loan applications have been received under this program, all of which were approved.

The volume of SBA business lending activities is summarized in table one:

TABLE I

Business Lending Activity of the Small Business Administration, October I953 Through December $195^{8}$

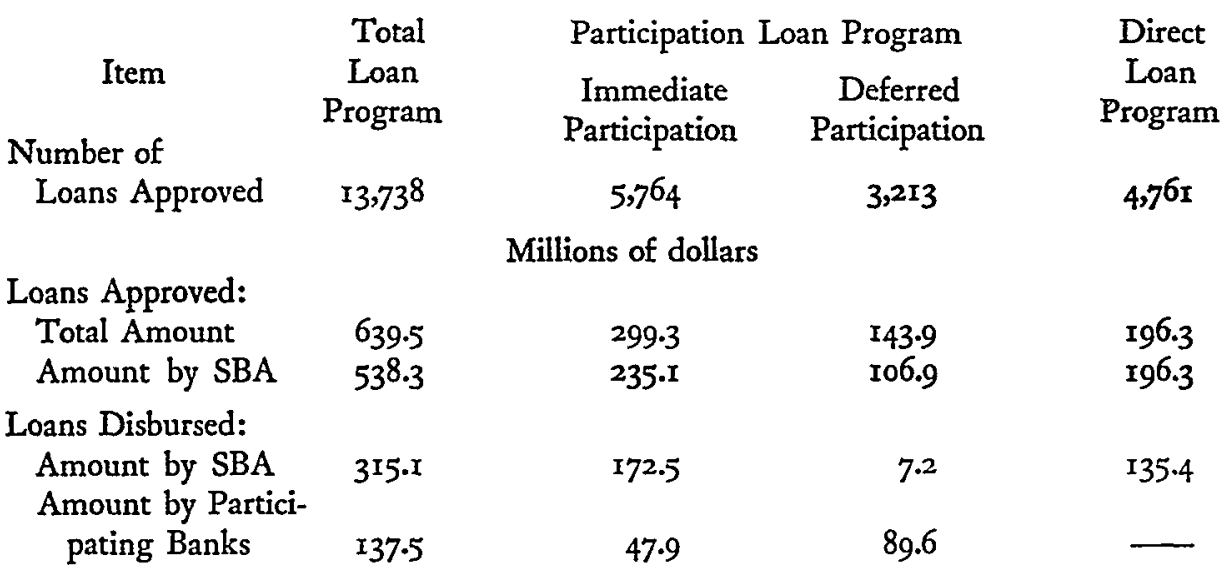

Financial assistance from the SBA is restricted to small businesses by eligibility requirements which specify that the concern must not be dominant in its field of operation and that it not exceed a specified size. In manufacturing, the size limitation is set in terms of number of employees. This employment standard varies from one manufacturing industry to another, but in no case does it exceed 1,000 . In nonmanufacturing industries, the size limitation is set in terms of dollar volume of business. Also the SBA statute sets a limit of $\$ 350,000$ on the amount that may be loaned to any one borrower. As a result of these operating limits, most of the SBA loans have been of small size. Of the $13,73^{8}$ business loans approved through December 3 , I958, 74.3 per cent of the number and 32.3 per cent of the total amount were for $\$ 50,000$ or less.

The SBA is also authorized to make loans to assist business concerns and home owners affected by floods, storms, and other natural disasters, and to assist business firms in drought or excessive rainfall areas which have suffered economic injury as a result of disaster conditions. Through December 31 , I958, 8, I30 disaster loans had been approved, amounting to $\$ 88,000,000$; of this amount, approximately $\$ 72,000,000$ had been disbursed. Although disaster loans are available to concerns of any size, 
most of them are made to small concerns. Moreover, many of those made to individuals are known to have been used for business purposes.

\section{IV}

\section{SBA Assistance in Obtaining Government Contracts}

The Small Business Act provides that ${ }^{23}$

the Government should aid, counsel, assist, and protect, insofar as is possible, the interests of small business concerns in order to preserve free competitive enterprise, to insure that a fair proportion of the total purchases and contracts for property and services for the Government (including but not limited to contracts for maintenance, repair, and construction) be placed with small-business enterprises, to insure that a fair proportion of total sales of Government property be made to such enterprises, and to maintain and strengthen the over-all economy of the nation.

The Small Business Administration is the principal spokesman within the federal government in connection with the administering and coordination of governmental efforts to assist small business firms to insure their receipt of a fair share of government contracts. Section fifteen of the Small Business Act ${ }^{24}$ empowers the Small Business Administration and government contracting officers to set aside procurements for competition solely among small business concerns. The set-aside program is one of the principal methods by which the Small Business Act assists small firms in obtaining a fair share of government contracts. SBA representatives are assigned to major government purchasing offices, where they screen all proposed purchases to determine whether small firms can supply the items or services and where they evaluate the small business competition which can be expected. When the Small Business Administration representative determines that sufficient small business competition can be obtained, he recommends that the procurement be totally or partially set aside for competitive award to small business concerns. Procedures are available within the procurement agencies for review of refusal to accept the recommendations of the Small Business Administration representative.

The set-side program is growing constantly. ${ }^{25} \mathrm{~A}$ table showing the agencies and departments cooperating with the Small Business Administration in carrying out the program, together with amounts of purchases set aside for small business concerns in fiscal year $195^{8}$ is given below. ${ }^{26}$

${ }^{23} 72$ STAT. 384 (1958), I5 U.S.C.A. $\$ 63$ I (Supp. 1959).

2472 STAT. 395 (1958), 15 U.S.C.A. \$ 644 (Supp. 1959).

${ }^{25}$ In fiscal year 1956 , the amount of purchases set aside was $\$ 497,678,432$. The figures for fiscal years 1957 and 1958 , respectively, are $\$ 744,335,298$ and $\$ 1,062,454,031$. Since the inception of the program until June 1958, 41,290 procurements, valued at $\$ 2,919,582,709$, have been set aside for small business concerns.

${ }^{20}$ Army

Navy

Air Force

Department of Commerce

General Services Administration

Veterans Administration

Department of Agriculture

Department of Interior

Post Office Department

$$
\begin{array}{r}
\$ 436,999,8 \times 2 \\
381,226,811 \\
192,973,955 \\
24,934,561 \\
13,591,673 \\
6,609,353 \\
3,021,267 \\
1,774,149 \\
1,222,450
\end{array}
$$


Complementing the set-aside program is the activity of Small Business Administration representatives designed to locate competent small business suppliers for those items or services for which small business competition has been lacking. Information obtained in connection with screening for possible set-aside action is used for this purpose. Where it is found that an item or a service could be supplied by small business firms, but there has been little or no small business competition in connection with that item or service in the past, SBA field offices attempt to locate competent small business suppliers of the item or service. This has the effect of expanding small business competition and broadening the industrial base, in addition to assuring a better price to the United States as a result of greater competition. It also increases the number and variety of items and services on which set asides for small business firms can subsequently be made.

In connection with its efforts to achieve maximum participation by small business concerns, the Small Business Administration maintains a facilities inventory. Small firms requesting assistance from the agency are requested to complete a questionnaire concerning their productive facilities and other related information. This information provides a record from which the Small Business Administration can ascertain the productive capacity of small business firms in a given area, and enables the agency to notify small business firms of prime contract or subcontract opportunities suitable to their facilities. It is also used to locate new sources for items or services on which competition is needed by Government purchasing offices. Further, the information is useful in connection with bid sets which the agency receives from many of the larger purchasing offices. By checking these bid sets against the facilities inventory, the agency is able to notify firms capable of supplying the item or service of procurement opportunities. ${ }^{27}$

Experience has shown that many firms have little or no idea of the nature of government procurement. In order to assist small business firms to compete effectively for government procurement, the Small Business Administration has instituted programs to bring government procurement requirements to the attention of small business concerns; it has also sought to clarify government procurement procedures. Small business concerns receive counseling on how to sell to the Government and information about the requirements of the various agencies. They are assisted in being listed on appropriate bidders' lists and in receiving bid sets for items or services which they are able to supply. The Small Business Administration publishes the U.S. Government Purchasing and Specifications Directory, which provides detailed information on items and services purchased by the Government, sources of specifications used by agencies in purchasing, steps to take in locating prime contract and subcontract opportunities, and other helpful data.

As part of this informational program and in order to bring its own programs to the attention of more small business firms, the Small Business Administration

27 Approximately 39,000 firms are presently registered with the Small Business Administration. During fiscal year 1958, more than 32,000 referrals of opportunities to small business concerns have been made by the agency. 
co-sponsors opportunity meetings. In fiscal year $195^{8}$, nineteen such meetings were held, with an estimated 12,375 small business owners and managers in attendance. At these meetings, through the media of talks by government purchasing officials, visual displays, sample bid sets, and other exhibits, those in attendance learned of government purchasing methods, prime contract and subcontract opportunities, and helpful government services. These meetings also featured exhibits by large prime contractors of items for which they welcome subcontracts. Purchasing agents were on hand at the meetings to discuss their requirements with small firms and to list firms on their bidders' lists for subcontract work and direct purchases.

The Small Business Administration assists small firms to solve problems regarding bids and specifications and helps to resolve difficulties between small firms and government procurement officials. ${ }^{28}$

Moreover, the SBA seeks to obtain copies of specifications from procuring agencies in time for small firms to submit a bid. The agency also reviews new and interim federal specifications received from the General Services Administration. Where the specifications appear to be too restrictive or discriminatory, the Small Business Administration recommends changes. In a number of cases, this has resulted in deletion or modification of specifications. The Small Business Administration also recommends new specifications or revisions in present specifications to enable small firms to compete by making their products eligible; and negotiations are held with a number of procuring agencies to accomplish this purpose.

The Small Business Administration also seeks to develop subcontracting opportunities for small business concerns. Due to a shift in the nature of Department of Defense purchasing, with its greater emphasis on missiles, aircraft, and other highly complex weapons purchased under the weapon-system concept, subcontracting opportunities are of increasing importance to small business concerns. The agency is intensifying its subcontracting program, tailoring it to the needs of small business firms under changing procurement conditions. The agency recently made available for use by its offices, as well as by the armed services, a directory entitled Missile Subcontracting, which contains information regarding (I) items used in the production of missiles, (2) assembly, subassemblies, and parts of missiles, and (3) companies engaged in the production of missile subsystem components, assemblies, sub. assemblies, and parts. The agency also compiles data on firms which have requested assistance in obtaining subcontracts. Agency representatives contact prime contractors and large subcontractors to interest them in subcontracting to these firms. ${ }^{20}$

Closely allied to the new weapons requirements of the Department of Defense is the recently increased demand for research and development. The Small Business Act provides, in substance, that the Small Business Administration is empowered

\footnotetext{
${ }^{28}$ In fiscal year I958, Small Business Administration field offices recorded almost 25,000 cases of procurement counseling and representation in behalf of small firms at purchasing offices. An additional 7,700 firms were helped to bid on specific procurements.

${ }^{29}$ In fiscal year $195^{8}$, Small Business Administration representatives made more than 3,000 of such calls and as a result, were able to refer approximately 6,500 opportunities to small firms.
} 
to assist small firms ( $\mathrm{x}$ ) to obtain government research and development contracts, and (2) to obtain the benefits of government-sponsored research and development. ${ }^{30}$ Further, the Act calls upon the Small Business Administration to provide technical assistance to small business concerns to achieve these objectives. ${ }^{31}$ The Small Business Administration is presently developing programs to achieve these objectives. ${ }^{32}$

The Small Business Administration field offices counsel and guide small firms and individuals interested in research and development work and direct them to appropriate procurement officials. The agency has issued a management aid on Research and Development Opportunities in the Federal Government, which describes steps to be taken by those firms seeking research and development work with the Government, lists the types of research and development contracts contracted for by civilian agencies, and explains which offices should be contacted by interested small firms.

Although much of the activity of the agency in connection with procurement assistance is directed at developing bidding opportunities for the small business concern and informs the small business concern of such opportunities, the agency also furnishes more direct assistance. An outstanding activity in this regard is the issuance of certificates of competency.

The Small Business Act authorizes the Small Business Administration to certify that small business concerns or small business defense production pools are competent, with respect to financial means and productive capacity, to perform specific government contracts. ${ }^{33}$ This determination by the agency is binding on the procuring authority in so far as financial and technical capabilities of the firm are concerned. The certificate of competency offers a method of appeal for a small business concern which-although low bidder on a procurement-has been rejected for lack of financial and productive capacity. After issuance of the certificate, agency representatives maintain a continual follow-up to assure that the contract is successfully performed. ${ }^{34}$

In summary, the Small Business Administration, in carrying out the mandate of Congress to assist and counsel small business concerns in the area of government procurement, has instituted various programs. Some of these are mainly informative in nature-providing information both to other government agencies and to small business concerns. Other activities are aimed directly at achieving more small business participation in particular government procurements.

${ }^{\text {so }} 72$ Stat. 39r (1958), I5 U.S.C.A. $\$ 638$ (b)(I) (Supp. I959).

${ }^{82}$ Id. $\$ 638(\mathrm{~b})(3)$.

82 The need for such assistance to small business concerns is indicated by the fact that only 3.7 per cent of the value of research and development contracts awarded by the military services in fiscal year 1958 was received by small business concerns.

${ }^{33} 72$ STAT. 389 (1958), 15 U.S.C.A. $\$ 637$ (b) (7) (Supp. 1959).

${ }^{36}$ In fiscal year 1958 , certificates of competency were issued on contracts amounting to more than $\$ 26,000,000$. Since the inception of the agency in August 1958, certificates have been issued on contracts having a total value of $\$ 64,000,000$. 


\section{$\mathrm{V}$}

\section{SmaIt Business Investment Act}

The Small Business Investment Act of $195^{35}$ was signed by President Eisenhower and became effective on August 2I, 1958 . The stated purpose of the Act is to improve the national economy in general and the small business segment thereof in particular by establishing a program to supplement the presently inadequate sources of private equity capital and long-term loan funds which small business concerns need for the sound financing of their business operations and for their growth, expansion, and modernization. ${ }^{36}$

Congress has directed that the program be conducted with a maximum participation of private financing. Further, it is the expressed intention of Congress that any financial assistance provided by the Government in this program shall not cause a substantial increase in unemployment in any area of the country, through industry pirating or otherwise. ${ }^{37}$

This legislation is designed to fill a gap in small business financing. Equity capital and long-term loans for growth and development purposes have never been readily available to small business. Commercial banks furnish short and intermediateterm loans, but not venture capital and long-term credit. Existing institutions which could provide venture capital are not able to assist smaller firms, since the cost for public sale of securities is disproportionately high to small business issuers. The Small Business Administration, under its regular lending program, can assist small business concerns with intermediate-term loans, but cannot provide the long-term funds needed for growth and development. As a result, there has been no institutional source to which small business could turn to meet its capital needs. It is this so-called institutional gap which the Small Business Investment Act of $195^{8}$ is designed to fill.

Under the Small Business Investment Act, the Small Business Administration has two main functions:

x. The Small Business Administration will license and regulate small business investment companies operating under the Act. The agency is empowered to charter private small business investment companies in states where such organizations cannot be organized or operate effectively under state law. These small business investment companies are to be devoted entirely to financing small business enterprises.

2. The second main function under this Act is to help these investment companies obtain financing by purchasing their debentures-and by making loans to them. Also, the Small Business Administration can lend money to existing state and local development companies that meet certain standards of operation where these loans will, in turn, be used to provide equity capital and long-term loan funds for small business concerns.

\footnotetext{
${ }^{35} 72$ STAT. 689, 15 U.S.C.A. $\$ \$ 66 \mathrm{I}-87$ (Supp. 1959).

${ }^{36} \$ 102,72$ STAT. 689, 15 U.S.C.A. \$ 66I (Supp. 1959).

${ }^{37}$ lbid.
} 
The new legislation provides the Small Business Administration with a revolving fund authorization of $\$ 250,000,000$ to make these loans, and approximately $\$ 50,000,000$ of this authorization has been budgeted for the remainder of the present fiscal year ending June 30 , $1959 .{ }^{38}$ The SBA will not be providing long-term financing to individual small businesses under this new legislation. Instead, it will assist in the creation of private small business investment companies, and will make loans to them and to state and local development companies. These companies, in turn, will make long-term financing available to individual small concerns, or provide them with equity-type financing. Thus, the federal government will have no direct relationship with small concerns under this program. The responsibility for investing in small business concerns, or making long-term financing available to them, rests with the small business investment companies.

The Act sets forth only basic and broad provisions and relegates to the Small Business Administration, as the administrative agency, the responsibility for establishing details and procedure. The SBA will select and license private corporations which will be chartered for the specific purpose of providing funds to small business concerns through the purchase of convertible debenture bonds of such concerns and the disbursement of long-term loans to such concerns. The activities of such corporations will be subject to regulations prescribed by the SBA, and such corporations will be examined by the SBA and will make reports as and when requested by the SBA. ${ }^{39}$

A small business investment company which has been licensed by the SBA will thereupon become eligible for financial assistance from the SBA, as provided under the Act, and will be eligible for discretionary exemptions by the Securities and Exchange Commission under the Securities Act of $1933^{40}$ and the Trust Indenture Act of $1939,{ }^{41}$ as well as an automatic exemption from the three-to-one asset to borrowings ratio required under the Investment Act of $1940 .{ }^{42}$ The Securities and Exchange Commission has issued its own regulations with respect to the discretionary exemptions available under these Acts. ${ }^{43}$ In addition, the company will become eligible for tax benefits specified under the Technical Amendments Act of $1958 .{ }^{44}$ Stockholders of such corporations are eligible also for tax benefits specified under the latter Act.

Section 57 of the Technical Amendments Act of 1958 contains three specific tax features amending the Internal Revenue Code of 1954. First, it provides that these investment companies are to be allowed an ordinary loss deduction, rather than a capital loss deduction, on losses realized on the convertible debentures (including stock received pursuant to the conversion privilege) acquired in connection with

${ }^{38} \S 202(a), 72$ STAT. 690, 15 U.S.C.A. $\$ 633$ (d) (Supp. I959).

${ }^{80}$ The Regulations under the Small Business Investment Act were promulgated on Dec. I, I958. See 23 FEd. Reg. 9383 (Dec. 4, I958).

1048 STAT. 74, I5 U.S.C. $\$ \$ 77 a-77 a a(1952)$.

1153 STAT. II 49 , I5 U.S.C. $\$ \$ 77 a a a-77 b b b b$ (I952).

1254 STAT. 789, I5 U.S.C. \$\$ 80a-I-80a-52 (1952).

ss Regulation E. 
the supplying of long-term equity-type capital for small business concerns. This loss deduction includes losses due to worthlessness, as well as those arising from the sale or exchange of the security. Second, taxpayers investing in the stock of the proposed investment companies also are to be allowed an ordinary loss deduction, rather than a capital loss allowance, on losses arising from the worthlessness, or from the sale or exchange of such stock. The third tax feature of this amendment provides that these investment companies are to be allowed a deduction for 100 per cent of the dividends received from a taxable domestic corporation, rather than eightyfive per cent deduction generally allowed corporate taxpayers.

Licensees ordinarily will be subject to the personal holding company tax imposed by section $54 \mathrm{I}$ of the Internal Revenue Code of $1954^{45}$ unless at no time during the last half of its taxable year more than fifty per cent in value of its outstanding stock is owned by or for any five or less individuals. Internal Revenue Service will issue regulations covering the tax benefits available to both a small business investment company operating under the Act and the investors therein.

As indicated, only small business concerns can be aided by the investment companies. The Small Business Investment Act regulations provide a definition of what constitutes a small business concern for the purposes of the Act. ${ }^{40}$ This definition, it is hoped, will permit ready indentification of the bulk of such concerns. The basic concept that a small business concern is one which is independently owned and operated and not dominant in its field of operations is retained. A wholly-owned subsidiary of another concern, or one which is under the control of another concern, is not prima facie independently owned and operated. A concern whose stock is listed on an exchange or traded over the counter is not prima facie small. Nor is a concern which has obtained public financing of over $\$ 300,000$ within three years. A noncorporate entity or one whose stock does not have a public market is not small if its total assets, together with those of all its affliates, amount to over $\$ 5,000,000$, or if its total income after taxes, including affliates, has averaged over $\$ 150,000$ per annum during the past preceding three years. However, any concern may apply to the SBA for a specific determination and certification as a small business concern.

Parties interested in the formation and licensing of a small business investment company for operation under the Act may file with the SBA a proposal or preliminary application on a form which can be obtained from the Washington or any regional or field office of the SBA. This proposal is a detailed document and should be given thorough and intelligent consideration in its preparation in order to justify serious consideration by the SBA. Among other matters, it must include the proposed name and operating territory of the prospective licensee. It must include copies of the proposed articles of incorporation and by laws of the proposed licensee, justification for the establishment of such company as a licensee in the proposed operating terri-

${ }^{45}$ See INT. Rev. CoDE of I954, $\$ \$ 541-547 ; 26$ C.F.R. I.54I-I-I.54I-7.

10 $107.103-I$ (Definitions). 
tory, proposed operating plans and policies, details with respect to the proposed capitalization of the company, the identification and background of proposed officers and directors of the company, and a plan for the expansion of the financial resources of the company as a licensee through the sale of its stock to private investors.

In considering whether to license an investment company, the SBA will give consideration to the need for financing by such company or small business concerns of the type the prospective licensee intends to assist. The character and ability of the proposed management to conduct the activities of the company so as to accomplish the purposes of the Act will be a controlling factor also in the licensing of a company.

Upon receipt of a proposal, the Small Business Investment Division will register the same and conduct such investigation as it deems appropriate. After consideration of the proposal, such applicants will be notified by the SBA whether the proposal, on its face, may justify further consideration of the issuance of a license to the company dealt with in the proposal. If so, the SBA will authorize the parties who filed the proposal to proceed with all action necessary to qualify their company for execution of a formal application and final consideration by the SBA as a licensee. Within ninety days from the date of such notice, the company should execute and submit to the SBA the formal application on a form to be supplied by the SBA, requesting the issuance of the license. Among other matters, the application will contain the offer of the company to conduct its activities under regulations prescribed by the SBA. After submission of the formal application, the SBA will issue a license if all requirements have been met.

Section 107.30I-I of the regulations under the Act sets forth the specific powers and authority which the charter of a licensee can contain. The charter must be limited to such powers, since the activities of a small business investment company operating under the Act must be devoted exclusively to the specific functions set forth in the Act. For instance, the charter of a licensee will permit the company to provide capital funds to small business concerns only through the purchase of convertible debentures. Only long-term loans, as defined by the SBA, can be made to small business concerns. Such loans will carry a maturity of not less than five years. The charter of a licensee will require that its operations be conducted in accordance with and subject to regulations prescribed by the SBA. While the operations of an investment company may be confined by charter or license to a specified geographical area, the company may do business with small business concerns located beyond such area.

The charter of a licensee must be obtained from the state or territory in which it operates, or if it operates in more than one state or territory, the charter will be obtained from any state or territory within the area of its operations. A licensee must be authorized or able to conduct its activities, as a domestic or foreign corporation, in the entire area in which it proposes to operate, in accordance with the provisions of its charter, the Act, and regulations prescribed by the SBA thereunder. 
The SBA will consider the issuance of a federal charter only if the parties are unable to obtain from a state or territory a charter containing the provisions required by the Act and SBA regulations, or if such a charter is available but restricted in such a manner that the company cannot operate in accordance with the purposes of the Act. An opinion of counsel and brief in support thereof dealing with reasons why a state or territory charter is unavailable must be submitted with a request for a federal charter.

The Act requires each licensee to have a paid-in capital and surplus equal to at least $\$ 300,000$. ${ }^{47}$ However, the SBA can purchase subordinated debentures of a company up to $\$ 150,000$, which shall be deemed a part of the capital and surplus of such companies for the purposes of the minimum capitalization required by the Act and for other stated purposes. Interest for such funds will be charged at the rate of five per cent per annum, and such obligations must have a stated maturity of not in excess of twenty years. Amortization must commence no later than the beginning of the second half of the term thereof.

Shares of stock of any class in a licensee can be issued by the licensee only in consideration for the simultaneous payment of cash to the licensee or as stock dividends. No shares may be issued for services, property, or any other noncash consideration.

SBA regulations require a licensee to make a full and complete disclosure of all matters to its prospective investors and shareholders. ${ }^{48}$ The licensee must submit to its shareholders and to the SBA an interim report containing financial statements covering the operations of the first six months of each fiscal year, and shall submit at the end of each fiscal year a report containing financial statements for the year and an opinion thereon by an independent certified public accountant based on an audit conducted in accordance with generally accepted auditing standards.

In addition to the subordinated debentures of a licensee which the SBA is authorized to purchase, the SBA can lend operating funds to a licensee up to fifty per cent of its paid-in capital and surplus, provided such funds are not available from other sources. Interest upon such loans will be at the rate of five per cent per annum, with maturities up to twenty years. Such loans can provide funds for new investments and loans by a licensee. These loans also can be a source for funds to protect the interests of a licensee in its investments and loans, until capital is obtained from private sources in sufficient amounts to provide cash for such purposes. By SBA regulation, the ratio of the total amount of outstanding indebtedness of a licensee to its paid-in capital and surplus cannot exceed four to one. ${ }^{49}$

Simultaneously with the disbursement by the SBA of any funds to a licensee, the executive officer and at least three members of the board of directors of the licensee must deliver a certificate to the SBA reciting that the licensee has not violated the Act, its charter, its license, or any regulations issued under the Act; that the capital of the

${ }^{47} 72$ STAT. 692, 15 U.S.C.A. $\$ 682$ (c) (Supp. 1959).

${ }^{48} \S 107.302-3$.

${ }^{40}$ \$07.303-1. 
licensee is not impaired; that the licensee will employ such funds within thirty days after receipt thereof in connection with the purchase of convertible debentures from or the making of long-term loans to small business concerns; and, that such funds will not be employed for any purpose which would cause a substantial increase in unemployment. The names of attorneys, agents, or others representing the licensee before SBA and any fees paid such parties must be disclosed. Further, the licensee must agree not to employ, within two years after disbursement of the funds, any person serving as an officer, attorney, agent, or employee of the SBA in a position involving discretion with respect to the granting of such financial assistance.

A licensee must maintain an unimpaired capital at all times. By SBA regulation an impairment will exist when, with the assets and liabilities (including debentures purchased by the SBA under section 302(a) of the Act) ${ }^{50}$ evaluated by sound accounting principles, the earned surplus deficit exceeds either the paid-in surplus or fifty per cent of the combined capital stock and paid-in surplus.

As indicated, a primary function of a small business investment company licensed for operation under the Act will be to provide a source of funds for the purchase of debenture bonds issued by small business concerns. Such funds must be used for the sound financing of the operations of and the growth, expansion, and modernization of such concerns. These bonds will be callable on any interest payment date, upon three months' notice, at the face value thereof plus accrued interest, and shall contain an option for the original holder, or any holder in due course thereof, to convert the same into stock of the small business concern, at any time up to and including the effective date of any call thereof by the small business concern.

Debenture bonds will be convertible into the number of shares of stock of such small business concern of an agreed type representing a total value equal to the face value of the bonds being converted. The value per share of said stock is required by the Act to be the sound book value thereof determined at the time of the issuance of the debentures. In computing such value, the regulations permit consideration of all pertinent factors, including the actual value of the assets of the small business concern and the relationship of the earnings of such concern to its invested capital.

The sale and purchase of such bonds will result from and be based upon the private negotiations between the small business concern and a licensee. This is in line with the principle stated earlier that the financial assistance to small business concerns made available under the Act will come from the privately owned and operated small business investment companies, and not from the Government. The SBA will not participate in the dealings between a small business investment company and a particular small business concern. The basic responsibility of the SBA under the Act is to establish and regulate the operations of small business investment companies in a manner which will accomplish the purpose of the Act through the stimulation and supplementation of private capital and loan funds for small business concerns. That is not to say that the SBA will not have an interest in small business

${ }^{50} 72$ STAT. 692, 15 U.S.C.A. $\$ 682$ (a) (Supp. 1959). 
concerns seeking and receiving benefits under the Act; its interest will be reflected in the regulation of the investment companies.

As a matter of initial regulation, the SBA has provided that the rate of interest to be stated in such bonds cannot exceed the maximum rate applicable to such transactions under local law. Should no legal limit exist, the rate may be established by the licensee, but subject to approval by the SBA.

The Act requires a small business concern that has been aided by a small business investment company through the purchase of convertible bonds to purchase capital stock of the licensee, at an agreed price, in an amount equal to not less than two nor more than five per cent of the amount of capital provided. ${ }^{51}$ The SBA has regulated this on a sliding scale basis, namely, two per cent up to $\$ 50,000$, three per cent up to $\$ 100,000$, and five per cent thereafter. ${ }^{52}$

In addition to the purchiase of such convertible debentures, small business investment companies operating under the Act will also provide long-term loan funds to small business concerns for the sound financing of the operations of and the growth, expansion, and modernization of such concerns. By regulation, the SBA has provided that the maturity of any such loans must be not less than five years, unless the loan is for the purpose of protecting the interests of a licensee in an existing long-term loan or for purchase of convertible debentures or stock..$^{53}$ It is intended that the Act and the regulations thereunder provide that such loans cannot give any right in a licensee to acquire stock or any other proprietary interest in the borrower, except through the medium of collateral security.

These long-term loans may be made by a licensee directly or in co-operation with other lending institutions through agreements to participate on an immediate or deferred basis. The initial maturity of such loans is limited to not in excess of twenty years, although a licensee may extend or renew the same for additional periods up to ten years if necessary for the orderly liquidation of the loan. The loans must be of such sound value, or so secured, as reasonably to assure repayment. By regulation, the SBA has provided that the rate of interest for a licensee's share of any such loan shall not exceed any applicable maximum rate..$^{54}$ If no maximum rate exists, the maximum rate of interest for a licensee's share will be determined by the SBA. As in the case of the purchase of convertible debentures, long-term loans will result from negotiations between a licensee and a small business concern.

Without prior written approval from the SBA, a small business investment company operating under the Act cannot hold aggregate obligations and securities of a particular small business concern in excess of twenty per cent of the combined capital and surplus of such licensee. Any stock of a small business concern shall be evaluated for such purpose on the basis of the agreed value thereof at the time of acquisition.

\footnotetext{
${ }^{51} 72$ STAT. 693, I5 U.S.C.A. $\$ 684$ (d) (Supp. 1959).

${ }^{20} \S 107.304-\mathrm{I}(\mathrm{h})$.

es क 107.305-I(b).

84 107.305-I(e).
} 
The SBA has provided that without its prior approval, a licensee will not be permitted to purchase convertible debentures of, or make a loan to, an officer, director, or owner of ten or more per cent of the stock of such licensee, or any relative thereof, or to any company in which such officer, director, owner, relative is an officer or director, or owns ten or more per cent of the stock, or is a partner.

Any funds of a licensee not reasonably needed for current operations may be invested only in direct obligations of, or obligations guaranteed as to principal and interest by, the United States Government. Hence, a licensee is limited in its investments to the purchase of convertible bonds of small business concerns and the making of long-term loans to them with interim investments, when its funds cannot be employed for such primary purposes, in obligations of, or those guaranteed by, the Government.

A potent medium for insuring compliance by small business investment companies with the provisions of the Act and regulations issued thereunder, will be the exercise by the SBA of its power of examination provided under the Act. Each licensee is subject to examination by the SBA with respect to any and all matters and at such times as may be determined by the SBA. It will be through the medium of examinations that the SBA will continually check whether a licensee is operating within the investment, loan, and other policies and plans which justified and induced the SBA to license the company initially.

Each licensee will be required also to submit reports to the SBA at the end of each six months' period of operation. Such reports will set forth in detail the current financial condition of the licensee and will include a review of the activities of the licensee during the period involved, with a statement and evaluation of assets acquired during such period. The SBA can call for interim reports covering such matters as it may determine.

Another feature of the Small Business Investment Act of $195^{8}$ is the assistance to be provided to state and local development companies. For identification purposes, SBA loans authorized under section 501 of the $\mathrm{Act}^{55}$ will be referred to as "50I loans," and those authorized under section 502 of the Act ${ }^{56}$ as "502 loans."

"50I loans" are limited to state development companies, and the total 5or loans outstanding at any one time to any one state development company cannot exceed the total outstanding borrowings of such company from other sources. Unless waived by the SBA, the rate of repayment of a 50 I loan will be at no lesser rate than other debts of the development company. 5or loans will bear interest at five per cent per annum and can run for periods up to twenty years.

Also, unless waived by the SBA under circumstances which would justify such action, ${ }^{\circ}$ I loans will be secured on a basis equal with other funds borrowed by the company after August 2I, I958, the date of enactment of the Act. This equality, however, may not require that all of an SBA loan be secured to the maximum degree

Ex $\$$ 501, 72 STAT. 696, I5 U.S.C.A. \$ 695 (Supp. 1959).

10 $\$ 502,72$ STAT. 697, I5 U.S.C.A. $\$ 696$ (Supp. 1959). 
that every other loan of the company is secured. By way of example, if the development company has borrowed an outstanding $\$ 20,000$, of which $\$ \mathrm{r} 0,000$ is secured by a first mortgage and $\$ 10,000$ is unsecured, and it borrows $\$ 15,000$ from the SBA, $\$$ Io,000 of this amount must be secured by a first mortgage, and $\$ 5,000$ of this amount may be unsecured.

A state development company may use the proceeds of 5 or loans to stimulate and supplement the flow of private equity capital and long-term loan funds which small business concerns need for the sound financing of their business operations and for their growth, expansion, and modernization and which are not available in adequate supply. Maximum participation of private financing sources must be obtained. Further, any financial assistance provided by the SBA must not result in a substantial increase of unemployment in any geographical area.

"502 loans" can now be made by the SBA to both state and local development companies, but the authority for such loans to local development companies expires on June 30, x96r. Such loans may provide funds to a development company only for the purpose of financing plant construction, conversion, or expansion, including the acquisition of land, to assist an identifiable small business concern in connection with a sound business purpose. Under SBA regulations, 502 loans may not be made to assist eleemosynary institutions; to aid the press, radio, or television; or to assist gambling or a small business concern which receives a substantial portion of its income from the sale of alcoholic beverages.

To obtain a 502 loan, a development company must show that a participation therein by another lending institution is not available. If the development company or the small business concern can obtain such financial assistance elsewhere, 502 loans will not be made. Interest on the SBA's share of a 502 loan will be $5^{1 / 2}$ per cent per annum. The maturity of such loans cannot exceed ten years plus such period as may be required for completion of construction, conversion, or expansion. Such loans, however, can be extended or renewed for an additional ro-year period to aid orderly liquidation. All 502 loans must be secured and may not exceed $\$ 250,000$ for each identifiable small business concern. 